\title{
IDENTIFYING DOCTORS' PROBLEMS IN BREAKING BAD NEWS: AN INITIAL STEP IN DEVELOPING RECOMMENDATIONS FOR THE CURRICULUM
}

\author{
Miko Ferine*, Gandes Retno Rahayu**, Mora Claramita** \\ * Faculty of Medicine, Universitas Jenderal Soedirman, Purwokerto - INDONESIA \\ ** Faculty of Medicine, Universitas Gadjah Mada, Yogyakarta - INDONESIA
}

\begin{abstract}
Background: The skill of breaking bad news is listed in the 2012 Indonesia's Doctor Competency Standards so that this becomes one of the skills that must be mastered by all doctors in Indonesia. The curriculum of breaking bad news is much developed in western cultural background. The curriculum may not necessarily be well developed in Indonesia because the communication process is strongly influenced by culture. Therefore, the exploration of the problems faced by the practitioner in delivering bad news in the context of local cultural needs to be done as a first step to develop the right educational curriculum and training.

Objective: This study aimed to identify problems of the practicing doctors in delivering bad news to patients or their families in the context of local culture (Banyumas).

Methods: This study was a qualitative research with a phenomenological approach. The method used was in-depth interviews to the practicing doctors with experience in delivering bad news selected from various educational backgrounds, sex, and age.

Results: This study indicated that the doctors had difficulty in breaking bad news. It was known from the attitude of the doctors who tended to avoid by giving the task to others, to cover the actual condition of the patient or just delivering the bad news to the family. The causes identified were the lack of knowledge and skills, the lack of ability to control emotions, the lack of confidence, the anxiety on the patient's response, the knowledge gap between doctors and patients, and the limitations of space and time.

Conclusion: The main problem of the practicing doctors in delivering bad news was the lack of knowledge and skills. Therefore, it is necessary to develop a training curriculum on breaking bad news adequately for basic and advanced medical education.
\end{abstract}

Keywords: doctor, breaking bad news, communication skills, curriculum development

\section{ABSTRAK}

Latar belakang: Keterampilan breaking bad news tercantum dalam Standar Kompetensi Dokter Indonesia 2012 sehingga menjadi salah satu keterampilan yang harus dikuasai oleh dokter di Indonesia. Proses komunikasi dalam breaking bad news sangat dipengaruhi oleh budaya. Kurikulum breaking bad news banyak dikembangkan dengan latar belakang budaya barat sehingga belum tentu dapat dikembangkan dengan baik di Indonesia. Oleh karena itu, eksplorasi mengenai permasalahan yang dihadapi dokter praktik ketika menyampaikan berita buruk dalam konteks budaya setempat perlu dilakukan sebagai langkah awal untuk mengembangkan kurikulum pendidikan dan pelatihan yang tepat. Penelitian ini bertujuan untuk mengidentifikasi masalah dokter praktik dalam menyampaikan berita buruk kepada pasien atau keluarganya dalam konteks budaya setempat (Banyumas).

Metode: Penelitian ini merupakan penelitian kualitatif dengan pendekatan fenomenologi. Metode yang digunakan adalah wawancara mendalam terhadap dokter praktik dengan pengalaman menyampaikan berita buruk yang dipilih dari berbagai latar belakang pendidikan, gender dan usia.

contact: mikoferine@gmail.com 
Hasil: Penelitian ini menunjukkan bahwa dokter mengalami kesulitan dalam menyampaikan berita buruk. Hal ini diketahui dari sikap dokter yang cenderung menghindari dengan menyerahkan tugas ini kepada orang lain, menutupi kondisi pasien yang sebenarnya atau hanya menyampaikan berita buruk kepada keluarga. Penyebab yang teridentifikasi antara lain kurangnya pengetahuan dan keterampilan, kurangnya kemampuan mengontrol emosi, kurangnya kepercayaan diri, kecemasan atas respon pasien, gap pengetahuan antara dokter dengan pasien, dan keterbatasan ruang dan waktu.

Kesimpulan: Masalah utama dokter praktik dalam menyampaikan berita buruk adalah kurangnya pengetahuan dan keterampilan. Oleh karena itu perlu dikembangkan kurikulum pelatihan penyampaian berita buruk yang memadai bagi pendidikan kedokteran dasar dan berkelanjutan.

Kata kunci: dokter, penyampaian berita buruk, keterampilan komunikasi, pengembangan kurikulum

\section{INTRODUCTION}

Effective communication skill, including the skill to break bad news, is one of the competence that gets the spotlight in healthcare. This skill is considered very important in healthcare, using patient-centered approach. Good communication does not only give the understanding to patients about their illnesses, but also satisfies patients about the care given. This certainly may affect the quality of doctor-patient relationship and improve the effectiveness of patients' therapy. ${ }^{1-3}$

Breaking bad news is considered as one of the most complex and difficult tasks by practitioners. A doctor is not only in charge to break bad news, but also to manage personal and patients' emotions during the communication process. A doctor often gets emotional when facing a patient's reaction and feel guilty because he/she has not been able to fulfill the patient's expectation. This process may cause the doctor and the patient or the family in a sad situation and often becomes a bad experience. ${ }^{3.5}$

The importance and difficulty of breaking bad news skill in practice has been realized by all parties, including observers of education in Indonesia. This skill must be mastered by all doctors, either in palliative care, emergency, or primary care. Standard Competence of Indonesian Doctors (SKDI) in 2012 published by the Council of Indonesian Medicine listed breaking bad news skill in the competence area of effective communication. There are only a few evidences that prove practice experiences will make it easy for a doctor to break bad news.
A doctor does not only need experiences, but also adequate knowledge and skills. $\mathrm{He} /$ she needs certain training or strategies to be able to break bad news well. Continuing communication training seems to be an important need for a doctor in doing his/her tasks. Therefore, the right education and training is an important key in developing the ability to break bad news. 3,7

The effort to develop a good training contains several continuous steps, including identification of problems, analysis of participants' needs, determining the objectives, strategy formulation, implementation and evaluation of training. ${ }^{8}$ The first step of developing the training of breaking bad news is to identify the problems faced by doctors in practicing breaking bad news. That information can be obtained from literature studies or field studies. Literatures about the process of breaking bad news can be found easily because studies about this topic have been developed much in developed countries since 1980s. Unfortunately, publications about the process of breaking bad news in Indonesian social and cultural context are not that many. In Indonesia, the national guide about the technique to break bad news that can be referred to in organizing education and training have not been developed. Several recommendations and guides used to break bad news are developed more with western cultural background., ${ }^{910}$ The reference that may be used is The Manual of Doctor-Patient Effective Communication published by the Council of Indonesian Medicine, but there is not a specific guide to break bad news. ${ }^{11}$ 
Culture affects the understanding of illnesses, morbidity, and death. Culture also affects the understanding of autonomic principles and goodness. Therefore, culture has a big impact to communication pattern, including doctor-patient communication related to breaking bad news. ${ }^{12}$ Guides from a few countries with western cultural background may not be used properly in Indonesia. To be able to develop a suitable training, a comprehensive field study is needed as one of the complementary of requirement analysis. The initial step that may be done is to explore the process of breaking bad news with local cultural background from the perspectives of the patient and the doctor.

According to above considerations, authors wanted to explore the problems faced by practitioners in breaking bad news to patients and their family. The results of this study were expected to be a recommendation for the development of the training of breaking bad news that is suitable with local cultural background.

\section{METHODS}

This is a qualitative study using phenomenology approach to explore the problems faced by practitioners in breaking bad news. ${ }^{13}$ This study was conducted in October 2015 to July 2016 after it was granted an ethical approval from Medical and Health Research Ethics Committee (MHREC) of Faculty of Medicine, Universitas Gadjah Mada.

The subject was practitioners in Banyumas Regency area, purposively chosen according to the established criteria with various work units, educational background, age, and sex. The informant criteria are: 1) practicing in Banyumas Regency at least one year; 2) having the experience of encountering patients with bad conditions and being responsible to break the bad news; 3) willing to be a study informant proven by the willingness to understand and to sign the informed consent. The process of recruiting informants continued to be done until data saturation was reached..$^{14}$ Saturation was reached by collecting data from 12 informants.
Data collection used in-depth interviews using semistructured interview guide format. There were 2 interviewers: the author and an assistant who had had the experience to do qualitative in-depth interview. Interview was recorded using an electronic voice recorder along with field notes to record expressions and details that could not be recorded in audio. Interviews were done informally in predetermined time and places. Interview process in this study lasted for about 47-66 minutes.

Data analysis began by transcribing the interviews. The interviews were transcribed manually, then the transcripts were given to the informants for confirmation and re-checking (member check). ${ }^{13}$ Informants needed to make sure that the transcripts were in accordance with what the informants meant during the interviews. All interview transcripts were read wholly to develop a general understanding of all information. Transcripts were coded by the author and other 2 other coders separately. The chosen coders had a master's degree and had the experience with qualitative studies. The results of the coding by the author were compared with the results by other coders and were discussed together to reach an agreement or the inter-coder agreement. ${ }^{15}$

The results of the coding were then grouped into categories and individual themes. Individual themes were interrelated, so the whole main theme of the study was reached. The effort to improve the credibility in data analysis and interpretation used peer debriefing involving 4 experts in the subjects of bioethics, psychology, and medical education.

\section{RESULTS AND DISCUSSION}

There were 12 informants in this study, 3 were general practitioners and 9 were specialist, 6 were males and 6 were females, 7 were younger than 45 years old and 5 were 45 years old or older. Informants were from various work units, including first, second, and third level of healthcare facilities. The characteristics of the informants were presented in Table 1. 
Table 1. Characteristics of informants

\begin{tabular}{lllllll} 
Code & $\begin{array}{c}\text { Age } \\
\text { (years) }\end{array}$ & Sex & Ethnicity & $\begin{array}{c}\text { Marital } \\
\text { status }\end{array}$ & $\begin{array}{c}\text { Educational } \\
\text { background }\end{array}$ & Work unit \\
A1 & 28 & Male & Javanese & Married & Bachelor - MD & Primary Health Care \\
A2 & 51 & Male & Javanese & Married & Bachelor - MD & Emergency Unit - Hospital \\
A3 & 39 & Female & Javanese & Married & Bachelor - MD & BPJS*) Clinic \\
B1 & 37 & Female & Javanese & Married & Specialist 1 & General Hospital \\
B2 & 40 & Female & Javanese & Married & Specialist 1 & General Hospital \\
B3 & 46 & Male & Javanese & Married & Specialist 1 & General Hospital \\
B4 & 49 & Female & Javanese & Married & Specialist 1 & General Hospital \\
B5 & 35 & Male & Javanese & Married & Specialist 1 & General Hospital \\
B6 & 42 & Female & Minang- & Married & Specialist 1 & General Hospital \\
& & & Javanese & & & General Hospital \\
B7 & 46 & Female & Javanese & Married & Specialist 1 & General Hospital \\
B8 & 35 & Male & Javanese & Married & Specialist 1 & General Hospital \\
B9 & 45 & Male & Javanese & Married & Specialist 1 & \\
\hline
\end{tabular}

*) BPJS is Indonesia's Universal Health Coverage Programme

The results demonstrated that every doctor realized that the information about the illnesses was the patients' right and the obligation of a doctor was to give that information to the patients. According to their practice experiences, many patients with bad conditions expected doctors to give them the information about the illnesses. Although a minority of doctors are able to break bad news directly to patients, there are still many practitioners who have the difficulties to break bad news. This is shown by practitioners' attitude and behavior who avoid the task to break the bad news, especially in end-of-life cases, including by: 1) handing the task to others who were considered to have better ability to break bad news; 2 ) breaking the bad news to the family without the patients knowing; 3) choosing to be dishonest and covering up the actual conditions; 4) not telling the prognosis of the diseases and distracting the patients.

Some doctors felt uncomfortable to break bad news to patients. They tried to avoid that task by handing it others, such as paramedics or patients' family.
Several doctors reckoned that in certain conditions, such as end-of-life condition, patients did not need to know their actual conditions. Doctors prioritized the ways to protect patients from dangerous situations. Keeping patients' bad conditions secret was considered more humane and ethical. ${ }^{12}$ Therefore, they chose to cover up patients' actual conditions and only told the truth to patients' family.

"Oh no, no, I don't tell the patients. I don't have the heart to do it. If they ask, I tell them to ask the paramedics." (B3)

"I tell them through their family, so... I tell them to tell the patients, but with a certain way or method that is usually done by the family to the patients. Because maybe, err, family know the patients better." (B8)

"Err, usually we don't tell the patients if they are in terminal illnesses. Or if they only receive palliative treatment we don't tell them, too. We only tell the family." (B4) 
The most difficult part of breaking bad news process is to explain patients' prognosis and life expectancy. These difficulties lead some doctors to be dishonest and cover up patients' actual conditions. Another strategy often used by doctors was to give incomplete information. The information given was only the diagnosis and its management. Meanwhile, the prognosis was not informed to the patients. If a patient asked, doctors tried to distract the patient or asked the patient not to think about it. The explanation of bad prognosis or low life expectancy was feared to harm the patient or the doctor. ${ }^{12}$

"Well, I won't tell them. We need to cover it up. I will say that... the disease is mild while in fact it's severe." (A2)

"...But if the patient who asks, I never say it. 'Doc, how long do I get?' Wow, I won't answer it. I always say that it's all God's plan, no need to worry, no need to be afraid. 'So, you must have the spirit for the next treatment'. No, I never tell them. I never tell them the prognosis." (B7)

This study also identified a few difficulties underlying a doctor's attitude and behavior to break bad news. Those difficulties are: 1) the lack of knowledge and skill to break bad news; 2) the perception of death as something sad and scary; 3) feeling guilty about patients' conditions; 4) the lack of confidence so doctors do not feel able to break the news well; 5) the anxiety about the patients' response or conditions after receiving the information; 6) knowledge gap between doctors and patients; and 7) limited time and place.

Practitioners' lack of knowledge about breaking bad news could be seen from the varying understanding of bad news by doctors. No doctor was able to explain the definition of bad news well. They tried to define it by giving examples of cases they often met in their everyday practices that were considered as bad news. Cases considered as bad news included terminal diseases, diseases with disabling complications, chronic or relapsing diseases, diseases with bad stigma, worsening diseases, genetic and congenital diseases, as well as many health problems causing psychosocial problems. According to those examples given, not all doctors were able to differ cases or diseases whether they were bad news or not according to the definition by Vandekieft. ${ }^{16}$

The lack of knowledge was also seen from doctors' lack of knowledge about certain guides or protocols that might be used as the guides to break bad news. Not many practitioners knew the guides or protocols to break bad news, both local or international ones, such as SPIKES protocol, BREAKS protocol, or ABDCE protocol. Doctors developed the steps to break bad news themselves based on their knowledge about diseases, the communication skills they had, and their experiences of facing patients with various cases and various characteristics.

"So far, I am a lay person, never read, about...err... journals or whatever about how to break bad news, usually I do it naturally. Never read it." (B7)

"In reality, well, that, err... if a patient is like this I must do what, if a patient is like that I must do what. If a patient is like this what is best I observe, maybe it's my habit." (B4)

Doctors' lack of skill to break bad news may be identified from their attitude and behavior in facing patients with bad conditions. As described above, some doctors were not able to break bad news directly to the patients. Some doctors also felt the difficulty to control their emotions and to response patients' conditions. ${ }^{17}$ This was caused by the lack of training of breaking bad news that could be taken by doctors, either in their basic or continuing education. Similar conditions are found in many developing countries. ${ }^{18,19}$

"I studied medicine and there was no special curriculum for communication. I think it should be included in the curriculum because it's important. Communication skill is actually not easy." (B2)

One of the factors affecting doctors' attitude and behavior in breaking bad news was their perception about the information about to be given. The perception of death as something sad or scary would hinder a doctor to break bad news to a patient. Emotional involvement was also an obstacle for 
a doctor to be able to break bad news directly to a patient. Although patients' illnesses were not the consequences of doctors' actions, sometimes doctors felt guilty because they were not able to help healing the patients. ${ }^{9}$ Doctors also often felt sad about patients' conditions.

'Maybe, err, verdict... Patients' verdict to have cancer seems like a verdict that their lives are not long. That's the scary part." (B7)

"But, err, sometimes I myself when delivering bad news sometimes got teary..." (A1)

"Because psychologically I feel guilty too to break the news. If the cases are cancer, HIV, I feel the burden to tell them because there must be... psychological impact later in the patients or family after hearing the news I say." (B7)

The unconfident feeling was also one of the main difficulties in breaking bad news. Some doctors felt they did not have enough skills to break bad news well. They worried their attitude or words were not right and made patients' conditions worse. Doctors also often worried if the patients were not mentally ready to receive bad information about their illnesses. Patients' worsening mental conditions were usually followed by worsening illnesses. ${ }^{20}$

"But I don't know, too, whether what I've been doing is right or not. Sometimes it's difficult to tell the patients..." (B9)

"Sometimes what I say is right. Sometimes, ouch, it's wrong. Ouch, I said something wrong, what to do, what to do. Like that..." (A3)

"Most patients are not ready to hear bad news. And if I worry patients to be depressed, I obviously won't tell it directly to the patients about the actual conditions." (B2)

The level of education and socio-economic condition of patients and their family affect the aims of breaking bad news. High level of education and socio-economic condition is one of the factors that makes it easy for doctors to break bad news. The information is given faster and easier to understand by the patients. On the contrary, low level of education and socio-economic condition is known to make patients care less about their health conditions. This may be related to the limited knowledge and ability to access adequate healthcare facilities. That condition increases the difficulty to break bad news.

"Because, well, if I tell them like that doesn't mean the patients understand. It's like, saying a lot of things would be...like... as you want it." (B4)

The high number of patients and limited human resources are two of the main health problems in Indonesia. ${ }^{21,22} \mathrm{~A}$ few doctors thought that the performance of doctors in Indonesia (including the informants) was under the international standards, including effective communication service.

"In my opinion, the main problem is time. Obviously in a rush. The delivered details are just the important ones. I can't say much in details about the diseases." (B8)

However, there are some things that may help practitioners to break bad news, including family role in Indonesian cultural context as well as belief of religions and local traditions. These often are used by practitioners as one of the strategies to break bad news to patients.

In Indonesia, with or without patients' permission, family is always involved in breaking bad news. The condition of a patient is not an individual problem, it is a family problem. This is one of the characteristics of Asian family, especially in countries whose population are mostly Muslims. ${ }^{18}$ The condition of a patient will be suffered by the family, too. Diseases requiring long-term care may burden the family, psychologically or economically. Family also have an important role in giving support as well as managing the patient.

Discussing with the patients' family may help doctors to overcome the difficulty of the process of breaking bad news. ${ }^{23}$ Patients' family may help doctors to confirm the information needed by the patients 
and at the right time to break the bad news. Family may also help doctors to prepare patients' mental to accept their conditions.

Indonesian society that is known to be religious and holding local traditions firmly become doctors' guide in breaking bad news. Sickness is believed to be God's will and to have certain wisdom for their sufferers. To be sick is one of the chances to lose their sins. Caring for a sick member of the family is also a chance to get rewards.

The interesting phenomenon in this study is that practitioners under 45 years old were more skillful to break bad news compared to 45 year-old practitioners or older. Younger practitioners seemed to have the confidence to break bad news directly to patients. Meanwhile, older doctors tended to break bad news to patients' family. This is different from the study by Locatelly et al. that demonstrated that younger doctors talk about patients' problems with their family. ${ }^{24}$

This phenomenon might be caused by knowledge and effective communication skills mastered well by younger doctors. This age group had received effective communication learning, both in medical school and in specialist school. Moreover, this phenomenon may prove that practice experiences would help doctors to break bad news. A doctor not only needs experience, but also adequate knowledge and skills. ${ }^{7}$

The development of breaking bad news curriculum is a need of basic and continuing medical education in Indonesia. The development of breaking bad news curriculum may be initiated locally as an initial step to prepare good curriculum.

Difficulties faced by doctors in everyday practice may be a consideration for education practitioners in developing breaking bad news curriculum. Indonesian society's characteristics of religiosity and holding eastern culture firmly that prioritizes family values and traditions also need to be considered, so that the process of breaking bad news may be applied according to the expectation of doctors and patients. Further studies are needed to explore the expectation and needs of society, especially patients related to breaking bad news.
This study may be done in other areas of Indonesia to enrich the information about the process of breaking bad news from the perspective of doctors. Higher number of informants is needed with more variation of settings, such as urban and rural areas.

\section{CONCLUSIONS}

According to the results, it can be concluded that breaking bad news to patients is still one of the difficult tasks for practitioners. This may be identified from doctors' attitude and behavior in facing patients with bad conditions (e.g. avoiding the task to break bad news and handing it to others, breaking bad news to family without the patients knowing, choosing to be dishonest to cover up patients' actual conditions, and not delivering the prognosis of the diseases by distracting patients). In addition, the difficulties faced by practitioners in breaking bad news are caused by lack of knowledge and skills to break bad news, misperception of death as something which is sad and scary, guilty feeling about patients' conditions, lack of confidence so doctors do not feel able to break the news well, anxiety of patients' response or conditions after receiving the information, knowledge gap between doctors and patients, and limited time and place. Finally, practitioners' problems in breaking bad news identified in this study may be a consideration for education practitioners in developing breaking bad news curriculum in basic and continuing medical education.

\section{REFERENCES}

1. Al-Mohaimeed AA, Sharaf FK. Breaking Bad News Issues: A Survey Among Physicians. Oman Medical Journal. 2013;28(1):20-5.

2. Hawken SJ, Henning MA. Constructing communication skills through preparation, experience, reflection and feedback. Medical Education Development. 2012; 2e6: 21-3.

3. Barnett MM, Fisher JD, Cooke H, James PR, Dale J. Breaking bad news: consultants' experience, previous education and views on educational format and timing. Medical Education. 2007;41: 947-56.

4. Rosenbaum ME, Ferguson KJ, Lobas JG. Teaching Medical Students and Residents Skills for Delivering 
Bad News: A Review of Strategies. Academic Medicine. 2004; 79:107-17.

5. Arbabi M, Rozdar A, Taher M, Shirzad M, Arjman M, Ansar S, Mohammadi MR. Patients' Preference to Hear Cancer Diagnosis. Iran Journal Psychiatry. 2014; 9(1):8-13.

6. Konsil Kedokteran Indonesia. Standar Kompetensi Dokter Indonesia. Jakarta: Konsil Kedokteran Indonesia; 2012.

7. Payan EC, Montoya DD, Vargas JJ, Velez MC, Castano A, Krikorian A. Barriers and facilitating communication skills for breaking bad news: from the specialists' practice perspective. Colombia Medica. 2009; 40(2):158-66.

8. Kern DE, Thomas PA, Hughes MT. Curriculum Development for Medical Education A Six Steps Approach. Maryland: The John Hopkins University Press; 2009.

9. Buckman R. Breaking bad news: why is it still so difficult? British Medical Journal. 1984;288:1597-9.

10. Baile WF, Buckman R, Lenzi R, Glober G, Beale EA, Kudelka AP. SPIKES-A Six-Steps Protocol for Delivering Bad News: Application to the Patient with Cancer. The Oncologist. 2000; 5: 302-11.

11. Konsil Kedokteran Indonesia. Komunikasi Efektif Dokter-Pasien. Jakarta: Konsil Kedokteran Indonesia; 2006.

12. Kagawa-Singer M, Blackhall LJ. Negotiating CrossCultural Issues at the End of Life "You Got to Go Where He Lives". Journal of American Medical Association. 2000; 286(23): 2993-3001.

13. Moustakas C. Phenomenological research methods. California: Sage Publications, Inc.; 1994.

14. Harper D, Thompson AR. Qualitative research methods in mental health and psychotherapy: A guide for students and practitioners. Sussex: John Wiley \& Sons, Ltd.; 2012.

15. Creswell JW. Research design: Qualitative, quantitative, and mixed methods approaches. Los Angeles: Sage Publication; 2009.
16. Vandekieft GK. Breaking Bad News. American Family Physician. 2001;64:1975-8.

17. Hulsman RL, PrangerS, KootS, Fabriek M, Karemaker JM, Smets EMA. How stressful is doctor-patient communication? Physiological and psychological stress of medical students in simulated history taking and bad-news consultations. International Journal of Psychophysiology. 2010; 77(20): 26-34.

18. Salem A, Salem AF. Breaking Bad News: Current Prospective and Practical Guideline for Muslim Countries. Journal of Cancer. 2013: 28; 790-4.

19. Tavakol M, Murphy R, Torabi S. Educating doctors about breaking bad news: an Iranian perspective. Journal Cancer Education. 2008; 23(4): 260-3.

20. Hagerty RG, Bullow PN, Ellis PM, Dimitry S, Tattersall MHN. Communicating prognosis in cancer care: a systematic review. Annuals of Oncology. 2005; 16: 1005-53.

21. Claramita M, Prabandari Y, van Dalen J, van der Vleuten CPM. Doctor-patient communication guideline that is tailored to Southeast Asian context. Southeast Asia Journal of Medical Education. 2010; 4(2): 23-30.

22. Castel OC, Ungar L, Mordechal A, Amiel GE, Karkabi K. Family Physicians' Perceptions, Beliefs and Attitudes Regarding Information Sharing with Prostate Cancer Patients Throughout The Course of The Disease. Support Care Cancer. 2008; 16: 955-61.

23. Martis L, Westhues A. A focus on the burdens, boosters and bonuses of the bearers of bad news in Indonesia. International Journal of Medical Education. 2013; 4: 126-38.

24. Locatelli C, Piselli P, Cichercia M, Repetto M. Physicians' age and sex influence breaking bad news to elderly cancer patients. Beliefs and practices of 50 Italian oncologists: the G.I.O.Ger study. PsychoOncology. 2013; 22: 1112-9. 